Open Access

\title{
Do employers in Myanmar prefer workers who accumulated skills in more advanced countries? Evidence from a field experiment
}

Saw Htay Wah

Correspondence:

sawhtaywah@gmaiil.com

Center for Economic and Social Research, University of Southern California, 635 Downey Way, Los Angeles, CA 90089-3332, USA

\begin{abstract}
I conducted an audit study in Yangon, Myanmar, to examine the effects of foreign labor market experience on employment outcomes in the Myanmar labor market focusing on three skilled occupation groups - software developer, accountant, and engineer-which combined account for more than $80 \%$ of all professional and technical job openings. I find heterogeneous effects by employer type (local, foreigner), occupation (software developer, accountant, engineer), and foreign country where such experience was accumulated (Singapore, Malaysia). In particular, I find a large and significant effect for software developers who accumulated experience in Singapore and no significant effect for the same experience accumulated in Malaysia; the Singapore effect is mainly due to foreign employers operating in Myanmar. In contrast, I find no significant effects of foreign experience for accountants and engineers. This is true for both the Singapore and Malaysia experiences, as well as for local and foreign employers.
\end{abstract}

JEL Classification: O15, J01, F22

Keywords: Return migration, Burma

\section{Introduction}

One prominent feature of international migration today is that a vast majority of migrants return to their country of origin after taking up employment or spending time in a host country for a certain period (Gibson and McKenzie 2011). Frequently cited economic reasons for returning include (1) higher returns in home countries to human capital accumulated in host countries (Dustmann, Fadlon and Weiss, 2007, 2011); (2) higher returns to self-employment activities in home countries relative to host countries (Dustmann and Kirchkamp 2002); (3) higher preferences for consumption in home countries (Dustmann and Weiss 2007); (4) a high purchasing power in home countries relative to host countries (Dustmann and Weiss 2007); (5) an increase in wage differentials between host and home countries (Dustmann 2003); (6) a fulfilment of a saving target that allows migrants to become entrepreneurs in home countries (McCormick and Wahba 2001; Wahba 2015; Mesnard 2004); and (7) worsening economic outlook in host countries relative to home countries. Non-

( ) The Author(s). 2018 Open Access This article is distributed under the terms of the Creative Commons Attribution 4.0 International License (http://creativecommons.org/licenses/by/4.0/), which permits unrestricted use, distribution, and reproduction in any medium, provided you give appropriate credit to the original author(s) and the source, provide a link to the Creative Commons license, and indicate if changes were made. 
financial factors such as personal preferences, social ties, and lifestyles are also found to be strong determinants of return migration (Gibson and McKenzie 2011).

Prior studies analyzing the effects of foreign experience find that return migrants are more likely than non-migrants to earn higher wages in home country labor markets (Wahba 2015; Reinhold and Thom 2013; Co et al. 2000; Barrett and Goggin 2010; Martin and Radu 2012). The effects are also found to differ by (1) gender (Co et al. 2000; Barrett and O'Connell 2001); (2) occupation (Reinhold and Thom 2013; Co et al. 2000); (3) host country or region where experience was accumulated (Co et al. 2000; Barrett and Goggin 2010; Carletto and Kilic 2011); and (4) education level of returnees (Barrett and Goggin 2010; Reinhold and Thom 2013; Barrett and O'Connell 2001; Barrett and Goggin 2010).

In this study, I examine the relationship between foreign labor market experience and employment outcomes that have received little attention in the extant literature. ${ }^{1}$ It is important to study employment outcomes because, despite possessing valuable skills and overseas experience, returnees could face barriers to full participation in local labor markets. For instance, a mismatch between skills acquired abroad and skills demanded by local employers (Sun, 2013) and a lack of cultural awareness and sensitivity may make returnees less attractive than non-migrants to potential employers in home countries, which could worsen employment outcomes for returnees. Or a lack of social ties and connections in the home country context after years of absence could lengthen their employment search process and thus unemployment spell (Martin and Radu 2012).

Examining the employment consequences of migration experience is hampered by the fact that migration is a highly selective process. For instance, Ambrosini et al. (2011), Wahba (2015), De Coulon and Piracha (2005), and Dustmann and Weiss (2007) find that migrants are positively selected relative to non-migrants. Similarly, in return migration, individuals who choose to return may fundamentally differ on both observed and unobserved characteristics from those who do not return. Indeed, prior studies show that returnees are both negatively (Wahba 2015; De Coulon and Piracha 2005) and positively selected relative to migrants who do not return (Ambrosini et al. 2011; Martin and Radu 2012). In addition, when analyzing the effects of return migration, one also has to address the bias associated with returnees self-selecting into specific occupations in home countries. For instance, compared to non-migrants, return migrants are more likely to become entrepreneurs (McCormick and Wahba 2001; Wahba 2015; Martin and Radu 2012). As a result, differences in outcomes between returnees and non-migrants reflect unobserved factors such as personality and motivation that can influence both migration decision and outcomes of interest (McKenzie et al. 2010; McKenzie 2012).

Given the highly selective nature of migration and return migration, studies analyzing the effects of foreign experience using conventional survey approaches may fail to uncover the true explanation for differences in outcomes between returnees and nonmigrants. In the outmigration literature, there are lottery programs (e.g., the US H-1B visa lottery and New Zealand visa lottery program) that enable researchers to causally estimate the return to migration (i.e., the impacts of people leaving their home country for other countries). ${ }^{2}$ In contrast, in return migration, there are no precedents for policy programs that will serve as a natural experiment allowing for causal inference of return migration. 
This study aims to address the shortcomings inherent in the use of conventional survey data approaches and provide causal estimates of the effects of foreign experience. In particular, this study employs a resume audit methodology that randomly assigns if a fictitious job applicant has foreign labor market experience or local experience. This methodology allows me to observe outcomes for returnees and non-migrants that are similar in both observable and non-observable characteristics, except for one important dimension-migration status. Then, any observed differences in outcomes between the two groups can be solely attributed to employers' reaction to migration experience. The resume auditing method has proven useful for studying differences in labor outcomes by race (Bertrand and Mullainathan 2004), age (Lahey 2008; Neumark et al. 2015), length of unemployment (Kroft et al. 2013), college education (Martorell et al. 2014), and nationality (Oreopoulos 2011).

In this paper, I present results from a resume audit study conducted in Yangon, Myanmar, that seeks to examine two questions: (1) how much demand exists for return Burmese migrants who accumulated computer programming, engineering, and accounting skills in Singapore and Malaysia, relative to similar workers who accumulated the same skills in the Myanmar labor market? and (2) does the demand for these skills acquired in Singapore or Malaysia differ by occupation, employer type, and foreign country? The resume audit study involved (1) submitting hundreds of fictitious resumes online in response to postings for skilled occupations (software developer and programmer, accountant, and engineer) by two kinds of employers (foreign and local) in the Myanmar labor market and (2) measuring callbacks for each resume submitted. Each resume was randomly assigned whether an applicant accumulated work experience in Malaysia or Singapore or in the Myanmar labor market.

Overall, I do not find statistically significant evidence that foreign experience is favored overall by employers in Myanmar. This aggregate effect however masks a great deal of heterogeneity by occupation, employer type, and foreign country. Specifically, software developers and programmers with foreign experience are highly favored, particularly if the experience was accumulated in the Singapore software industry. When selecting on employer type, I find that the effect of Singapore experience is mainly driven by foreign employers in Myanmar. In contrast, I find no significant effects of foreign experience for accountants and engineers. This is true for both the Singapore and Malaysia experiences, as well as for both local and foreign employers.

This paper contributes to the existing literature on return migration in two ways. First, it addresses the endogeneity of return migration and provides causal estimates of foreign experience. Second, it helps better understand heterogeneous effects by occupation, employer, and foreign country where experience was accumulated. It also contributes to a growing list of labor market audit studies conducted in developing country settings (e.g., Galarza and Yamada 2014; Banerjee et al. 2009; Bóo et al. 2013).

The remainder of the paper is organized as follows. Section 2 presents the experimental design and describes the sample and data source used in this analysis. Section 3 details empirical analysis, followed by a presentation of the findings in Section 4. Section 5 concludes.

\section{Experimental design}

The experiment was conducted in Yangon, Myanmar. With a population of over 6 million, Yangon is the cultural, commercial, and financial capital of Myanmar, home to 
over $90 \%$ of all registered businesses, and thus accounts for a vast majority of private sector jobs. When it comes to examining how returning skilled migrants can potentially close the skills gap and strengthen a local labor market in a developing country, Myanmar offers an excellent case study due to its unique economic and political history. Since its independence from Great Britain in 1948, Myanmar was ruled by three consecutive military regimes until 2015 when the first democratically elected civilian government came to office in the country's history. During decades of military rule, crackdowns on students, political oppression, and severe economic hardships triggered a departure of the skilled and talented to other countries in search of better economic opportunities. Meanwhile, absent meaningful educational reforms, the country's higher education system was unable to produce graduates equipped with the skills employers needed. Although no official statistics are available, anecdotal evidence suggests that a large number of Burmese migrants work as engineers, skilled laborers, surveyors, IT analysts, and nurses in more advanced countries (relative to Myanmar) such as Singapore and Malaysia. Many of these migrants have worked for international firms and accumulated skills consistent with global standards. Thus, they could be a potential source of skills for employers in Myanmar if programs and policies designed to attract them to return home can be put in place. ${ }^{3}$ The historical context and current political climate of Myanmar provide a unique opportunity to explore how return migrants fare in the labor market, which will generate policy implications specific to Myanmar but also applicable to other developing countries facing shortages of sufficiently skilled workers.

Preparation of resumes began with sampling job openings and collecting job requirements from job advertisements each week. I then prepared resumes meeting those requirements in terms of educational attainment, years of work experience, salary requirement, and relevant computer skills. For each job posting, I prepared two resumes, and for each resume, I randomized the following variables: (1) country where an applicant accumulated labor market experience (local/foreign) and (2) foreign country (Singapore/Malaysia) conditional on being assigned foreign experience. The choice of Singapore and Malaysia labor markets in this application is meant to reflect the actual situation that most skilled Burmese migrants work in these countries. In addition, the characteristics of the Singapore and Malaysia labor markets are fundamentally similar to those of Myanmar. For instance, although workers are allowed to form unions in these three Southeast Asian countries, their collective political clout is relatively limited and labor rights are significantly curtailed, compared with those found in liberal democracies in western countries; protests by workers are rarely tolerated and often suppressed immediately. Thus, we can rule out Myanmar employers' concern that returnees who have been exposed to the Singapore and Malaysia labor markets might demand excessive political rights and stage protests.

If an applicant had foreign experience, this information was salient to employers in the subject line of the emails sent to employers by listing "[Position applying for]: Applicant with work experience in Singapore/Malaysia," as well as in the content of the application letter by listing "I had relevant work experience in Singapore/Malaysia." In addition, foreign experience is also salient in the resume by listing an applicant's last three foreign employers and their foreign addresses. Each resume listed the job title, period of employment, and company name of an applicant's recent three jobs in reverse 
chronological order. The total years of work experience listed in the resume were always the same for both applicants and met the job requirements. Each resume was randomly assigned three companies where the applicant previously worked from a list of companies that were carefully chosen from two company registries based on two criteria: they (1) are of small size (most employing less than 20 persons) and (2) lack reputation and recognition at the national and international levels. This effectively rules out the possibility that potential employers might infer labor productivity from previous employments and their prior belief about the quality of previous experience. ${ }^{4}$ Both applicants were unemployed and looking for employment. Similarly, age of applicant, year of graduation, college major, university, computer skills, and other related skills were the same for both resumes. One of the resumes was randomly assigned a female name and the other a male name. For job openings with gender restriction, both resumes were assigned the same gender. Gender requirement for a job opening was always mentioned in the advertisement. Name of an applicant was always listed at the top of the resume with a large font size. Address and contact information were listed below the name. The resumes themselves were designed based on a large pool of actual resumes used by applicants in the Myanmar market and thus representative of actual job seekers. A pair of resume samples prepared for a site engineer position is provided in Additional file 1, with resume sample 1 belonging to an applicant with Malaysia experience and resume sample 2 belonging to a local experience. While each employer was sent two resumes, they were sent at least a day apart. Each resume was randomly assigned a template and a cover letter. The font and layout choices were also randomized. Because the number of features randomized by the experiment was large, it was unlikely that the resumes would have similarly listed characteristics to describe the applicants. Furthermore, different fonts and layouts were used for each resume sent to an employer. Thus, it is very likely that employers viewed each resume as coming from an independent and real applicant.

Finally, resumes were saved as word files and randomly submitted via emails (independent of any resume characteristics) to employers over a 2-day period (Wednesday to Thursday) in each of the 19 weeks between March 23, 2015, and August 7, 2015. Unsuccessful applications due to incorrect employers' email addresses, which constitute less than $1 \%$ of the sample, were dropped from the sample.

The sample for job openings is from a popular magazine among job seekers in Myanmar (Opportunity; http://www.opportunity.com.mm/). The magazine carries only job advertisements, is published weekly, and accounts for approximately $90 \%$ of all job advertisements in the country. Job openings are classified by industrial sector: (1) production and manufacturing, (2) construction, (3) tourism, (4) IT, (5) trading, (6) service, and (7) non-government organizations (NGO) and international non-government organizations (INGO). I restrict the sample to (1) skills-intensive and professional job categories; (2) job openings that require applicants to submit resumes via email; and (3) non-NGO and non-INGO jobs. I also restrict the sample to one randomly selected job opening per employer although several employers list multiple job openings in a given week. Each company is uniquely identified by a combination of information available in the advertisements, including company name, address, phone number, and email; I use this information to ensure that each company is sampled only once in the event that a company's job advertisements show up in several issues of the Opportunity magazine during the study period. 
Only the occupations of software developer and programmer, accountant, and engineer are chosen for this study because they represent growing occupations as Myanmar has been trying to move from an agriculture-based economy toward a service-, manufacturing-, and production-based economy. An examination of the Opportunity magazine reveals they account for more than $80 \%$ of all professional and technical job openings in a typical week. A close investigation of all job advertisements also reveals no systematic differences in job openings between foreign and local companies in terms of qualification, job title, and advertisement content. In addition, job titles within each occupation group tend to be homogeneous. For instance, job titles for most accounting jobs are either accountant or senior accountant. Myanmar has seen a gradual increase in the inflow of foreign direct investment since 2011 when it opened up, resulting in an increased number of foreign companies and multinational corporations operating in Myanmar. ${ }^{5,6}$ Further, as the Myanmar economy is projected to grow at an annual rate of approximately $8 \%$ in the coming years, according to the World Bank, ${ }^{7}$ a shortage of workers with sufficient skills among these occupation groups will be an issue for both local and foreign employers in the coming years. The distribution of sample job openings, broken down by occupations, is provided in Appendix 1. Broadly, 46\% of them can be grouped as accountant, $39 \%$ as engineer, and 14\% as software developer or programmer.

\section{Empirical analysis}

The outcome used in prior resume audit studies (e.g., Bertrand and Mullainathan 2004; Kroft et al. 2013; Lahey 2008; Oreopoulos 2011) is if a resume submitted receives a callback for an interview. I study additional outcomes because of the unique challenges-relative to the literature-faced by conducting this method in Myanmar. First, employers in Myanmar do not rely as heavily on resumes in terms of screening applicants and inferring productivity, compared with employers in other developed countries, in particular the USA. Rather, personal interview combined with oral examination about knowledge on relevant subjects is the preferred method for screening applicants. Second, the marginal cost to interview an applicant is very low in Myanmar. As a result, a high percentage of applicants is interviewed for a job opening, making resumes relatively less effective as a screening device and thus weakening the effects of listing any resume characteristics (e.g., foreign experience). This study finds that the average callback rate is $22 \%$, compared to $3-5 \%$ found in prior studies. Moreover, in prior resume audit studies, information regarding whether a resume submitted receives a callback is retrieved from content of the voice message left by the employer. In contrast, employers in Myanmar rarely leave voice message, and whenever an employer calls back, a trained auditor pretending to be the applicant has to answer the call and is instructed to mention to the employer over the phone that he/she is no longer interested in the employment opportunity. As a result, the employer is more likely to call back the second applicant for an interview.

To circumvent this issue and uncover an employer's interest in an applicant, I focus on the following outcome: if a resume submitted is the first to receive a callback for an interview. The outcome produces variation even when employers call back both applicants, and some of this variation may be informative about employers' preferences. As a robustness check, I also consider another outcome: if a resume submitted receives a 
callback for an interview conditional on employers calling back only one applicant out of two. This outcome eliminates employers that are calling back both applicants and, instead, focuses on employers that are more likely to be making active hiring decisions based on the resume characteristics. ${ }^{8}$

To assess the effect of foreign work experience on the outcome variables, I estimate the following model by OLS.

$$
Y_{i j t}=\beta_{0}+\beta_{1} * \text { foreign }_{i j t}+\omega X_{i j t}+\gamma_{t}+\varepsilon_{i j t}
$$

where the indices have the following meaning: resume $i$ gets submitted to employer $j$ in week $t . Y_{i j t}$ is the outcome variable of interest. The term $\varepsilon_{i j t}$ is an error. "Foreign" is a treatment variable taking a value of 1 if a resume is associated with foreign experience and zero otherwise. I report all standard errors adjusted for clustering at the employer level (Bertrand and Mullainathan 2004; Oreopoulos 2011). $X$ is a vector of randomly assigned resume characteristics that include resume template fixed effects, resume cover letter fixed effects, resume address fixed effects, and gender of an applicant. The regression model also controls for week fixed effects captured by $\gamma_{t}$. The parameter of interest, $\beta_{1}$, captures the average effect of listing foreign experience on the outcome variable. Given that resume characteristics are randomized, their inclusion should not matter but will help reduce unexplained error, thereby improving the statistical precision of estimates of the treatment effects. To investigate if the effect of foreign experience varies by foreign country where experience was accumulated, I disaggregate the total treatment effect by introducing dummies for Malaysia and Singapore separately. To assess if callback rates are different across employer subgroups (foreign, local) and occupation subgroups (accountant, software developer, engineer), I restrict the sample according to the subpopulation of interest and report results for each subpopulation group separately. For each specification and sample restriction, I report OLS results with and without controls and $p$ values adjusted for multiple hypothesis tests using Holm's method (Holm, 1979). Standard errors are clustered at the employer level.

\section{Results}

Table 1 presents the results for mean equality tests of the randomly assigned resume characteristics. The last column reports $p$ values, with the null being that the means are equal between local and foreign applicants. The results suggest that randomization was successful. Table 2 lists callback statistics and shows that the average callback rate is $22 \%$, which is significantly higher than $3-10 \%$ found in prior studies (e.g., Bertrand and Mullainathan 2004; Kroft et al. 2013; Lahey 2008; Oreopoulos 2011; Galarza and Yamada 2014). About $72 \%$ of employers did not call back any applicants, $13 \%$ call back one of the two applicants, and 15\% call back both applicants. Descriptive statistics of the treatment variables and randomly assigned resume characteristics are also provided in Table 2. Of 1938 resumes submitted, 50\% are assigned foreign work experience, and conditional on being assigned foreign experience, $50 \%$ of the resumes are associated with the Singapore labor market experience and 50\% with the Malaysia labor market experience. Each of the four resume templates is equally represented. About $52 \%$ of resumes are associated with female names, and 50\% are associated with an address in a rich neighborhood. The average age of applicants is 27 years, and half of the resumes are assigned application cover letter \#1. 
Table 1 Randomization tests

\begin{tabular}{lccc}
\hline & \multicolumn{2}{l}{ Sample means } & \multicolumn{2}{c}{\begin{tabular}{l}
$p$ value of test of mean \\
\cline { 2 - 4 } equality
\end{tabular}} \\
\cline { 2 - 4 } Local applicants & Foreign applicants & 0.87 \\
Resumes associated with template 1a & 0.25 & 0.25 & 0.09 \\
Resumes associated with template 1b & 0.27 & 0.24 & 0.09 \\
Resumes associated with template 2a & 0.24 & 0.27 & 0.87 \\
Resumes associated with template 2b & 0.25 & 0.25 & 0.93 \\
Female applicants & 0.52 & 0.52 & 0.16 \\
Resumes associated with rich neighborhood & 0.52 & 0.48 & 0.96 \\
Resumes associated with cover letter \#1 & 0.50 & 0.50 &
\end{tabular}

Table 3 panel A presents the OLS results where I pool all occupation groups. The results in column 1 suggest that there is no statistically significant effect of listing foreign labor market experience on receiving a callback first for an interview. This point estimate is unaffected by the inclusion of additional controls in column 2. Columns 3 and 4 report the results for the subsample of local employers, revealing no statistically significant difference in first callback rates between local and foreign applicants either. I reach the same conclusion when selecting on foreign employers in columns 5 and 6. I then disaggregate the total effect of foreign experience into the Singapore and Malaysia experiences by introducing country dummies (Table 3 panel B). The point estimates suggest that the Singapore labor market experience is favored by foreign employers and less favored by local employers and the Malaysia labor market experience is less favored by

Table 2 Descriptive statistics

\begin{tabular}{|c|c|c|c|c|}
\hline & Number & Mean & Min & Max \\
\hline \multicolumn{5}{|l|}{ Callback } \\
\hline Resume is the first to receive a callback for interview & 1938 & 0.14 & 0 & 1 \\
\hline Resume receives a callback for interview & 1938 & 0.22 & 0 & 1 \\
\hline Job openings in which no applicants receive callbacks & 969 & 0.72 & 0 & 1 \\
\hline Job openings in which only one applicant receives callback & 969 & 0.13 & 0 & 1 \\
\hline Job openings in which both applicants receive callbacks & 969 & 0.15 & 0 & 1 \\
\hline \multicolumn{5}{|l|}{ Treatment variables } \\
\hline Foreign experience & 1938 & 0.50 & 0 & 1 \\
\hline Malaysia experience/foreign experience & 969 & 0.50 & 0 & 1 \\
\hline Singapore experience/foreign experience & 969 & 0.50 & 0 & 1 \\
\hline \multicolumn{5}{|l|}{ Covariates } \\
\hline CV template $1 a$ & 1938 & 0.25 & 0 & 1 \\
\hline CV template $1 \mathrm{~b}$ & 1938 & 0.25 & 0 & 1 \\
\hline CV template $2 a$ & 1938 & 0.25 & 0 & 1 \\
\hline CV template $2 \mathrm{~b}$ & 1938 & 0.25 & 0 & 1 \\
\hline Resumes with female names & 1938 & 0.52 & 0 & 1 \\
\hline Resumes associated with rich neighborhood & 1938 & 0.50 & 0 & 1 \\
\hline Age of applicant & 1938 & 26.57 & 24 & 37 \\
\hline Cover letter \#1 & 1938 & 0.50 & 0 & 1 \\
\hline
\end{tabular}


Table 3 Dependent variable: if a resume is the first to receive a callback for an interview (all occupations)

\begin{tabular}{|c|c|c|c|c|c|c|}
\hline & \multicolumn{2}{|c|}{ Local and foreign } & \multicolumn{2}{|l|}{ Local } & \multicolumn{2}{|l|}{ Foreign } \\
\hline & (1) & (2) & (3) & (4) & (5) & (6) \\
\hline \multicolumn{7}{|l|}{ Panel A } \\
\hline \multirow[t]{2}{*}{ Foreign experience } & -0.007 & -0.007 & -0.013 & -0.014 & 0.015 & 0.008 \\
\hline & $(0.017)$ & $(0.017)$ & $(0.019)$ & $(0.019)$ & $(0.041)$ & $(0.043)$ \\
\hline \multirow[t]{2}{*}{ Constant } & 0.146 & 0.178 & 0.140 & 0.154 & 0.165 & 0.317 \\
\hline & $(0.011)^{* * *}$ & $(0.039)^{* * *}$ & $(0.013)^{* * *}$ & $(0.042)^{* * *}$ & $(0.026)^{* * *}$ & $(0.103)^{* * *}$ \\
\hline Controls & No & Yes & No & Yes & No & Yes \\
\hline$N$ & 1938 & 1938 & 1538 & 1538 & 400 & 400 \\
\hline$R^{2}$ & 0.000 & 0.019 & 0.000 & 0.024 & 0.000 & 0.039 \\
\hline \multicolumn{7}{|l|}{ Panel B } \\
\hline \multirow[t]{2}{*}{ Malaysia } & -0.015 & -0.018 & -0.012 & -0.016 & -0.025 & -0.039 \\
\hline & $(0.020)$ & $(0.020)$ & $(0.022)$ & $(0.022)$ & $(0.047)$ & $(0.048)$ \\
\hline \multirow[t]{2}{*}{ Singapore } & 0.000 & 0.003 & -0.014 & -0.011 & 0.050 & 0.047 \\
\hline & $(0.021)$ & $(0.021)$ & $(0.022)$ & $(0.022)$ & $(0.051)$ & $(0.053)$ \\
\hline \multirow[t]{2}{*}{ Constant } & 0.146 & 0.179 & 0.140 & 0.154 & 0.165 & 0.319 \\
\hline & $(0.011)^{* * *}$ & $(0.039)^{* * *}$ & $(0.013)^{* * *}$ & $(0.042)^{* * *}$ & $(0.026)^{* * *}$ & $(0.105)^{* * *}$ \\
\hline Controls & No & Yes & No & Yes & No & Yes \\
\hline$F($ Singapore $=$ Malaysia $)$ & 0.46 & 0.84 & 0.01 & 0.03 & 1.95 & 2.46 \\
\hline$N$ & 1938 & 1938 & 1538 & 1538 & 400 & 400 \\
\hline$R^{2}$ & 0.000 & 0.019 & 0.000 & 0.024 & 0.005 & 0.045 \\
\hline
\end{tabular}

Standard errors (clustered at the company level) are in parentheses. Controls include week fixed effects, resume template fixed effects, resume cover letter fixed effects, gender of an applicant, and a dummy indicating if a resume is associated with an address in a rich neighborhood. The $F$-statistics are $F$-tests for the Singapore and Malaysia effects being equal ${ }^{*} p<0.10$; ${ }^{* *} p<0.05$; ${ }^{* *} p<0.01 . p$ values are adjusted for multiple hypothesis tests using Holm's method (Holm 1979)

both local and foreign employers, though the estimates are not statistically significant.

The aggregate results presented in Table 3 may mask heterogeneity by occupation. Before investigating heterogeneity across three occupation groups-(1) software developer or programmer, (2) accountant, and (3) engineer-it may be helpful to explain first why we might expect heterogeneous effects by occupation, given the unique setting and context of this study. Compared to universities in other ASEAN countries, degree programs on computer studies were introduced relatively late by Myanmar universities. Founded in 1971, The Yangon University of Computer Studies (http://www.ucsy.edu.mm/ucsy/) was the only higher educational institution granting degrees in computer studies until 1997, when a second University of Computer Studies was opened in the city of Mandalay (http:// www.ucsm.edu.mm/). The lack of meaningful educational reforms, prolonged closure of universities, and significantly curtailed school duration during the military rule negatively affected the skill levels of many university graduates, including those who attended the two computer universities. Further, the development of the Myanmar software industry was hampered by decades of isolation and economic sanctions that restricted inflows of IT technologies, personnel, and tech firms from more developed countries. Since the country opened up in 2011, there has been an increase in the demand for skilled IT and software personnel, and this increased demand is mainly fueled by a boom in the service industry. Unlike computer 
science, knowledge about accountancy has been well established within local institutions and companies. Similarly, unlike the two computer universities, Myanmar engineering schools are relatively old, dating back to the British colonial period. ${ }^{9}$ Thus, knowledge about engineering is more developed and diffused than computer science within the Myanmar higher education system.

Table 4 panel A reports the results for the subsample of software developers or programmers, which constitute $14 \%$ of the sample job openings. The results show that, on average, software developers and programmers with foreign labor market experience are 18.9 percentage points more likely than equivalent applicants with Myanmar experience to receive callbacks first from employers and the difference is significant at the $5 \%$ level. This difference in first callbacks represents about a $116 \%$ effect relative to the baseline estimate of 16.2 percentage points. This relationship is largely unchanged when I add controls in column 2. When disaggregating the total treatment effect into local and foreign employers in columns 3 and 5, the positive effect of foreign experience reported in column 1 is mainly attributed to foreign employers. Specifically, foreign employers hiring software developers and programmers are 33.3 percentage points more likely to first call back an applicant who acquired skills abroad; the point estimate is statistically significant at the $10 \%$ level and equivalent to a $140 \%$ effect relative to the baseline callback rate of 23.8 percentage points (column 5). In contrast, I

Table 4 Dependent variable: if a resume is the first to receive a callback for an interview (software developer/programmer)

\begin{tabular}{|c|c|c|c|c|c|c|}
\hline & \multicolumn{6}{|c|}{ Software developer/programmer } \\
\hline & \multicolumn{2}{|c|}{ Local and foreign } & \multicolumn{2}{|l|}{ Local } & \multicolumn{2}{|l|}{ Foreign } \\
\hline & $(1)$ & (2) & (3) & (4) & (5) & (6) \\
\hline \multicolumn{7}{|l|}{ Panel A } \\
\hline \multirow[t]{2}{*}{ Foreign experience } & 0.189 & 0.190 & 0.132 & 0.127 & 0.333 & 0.233 \\
\hline & $(0.081)^{* *}$ & $(0.086)$ & $(0.086)$ & $(0.096)$ & $(0.189)^{*}$ & $(0.221)$ \\
\hline \multirow[t]{2}{*}{ Constant } & 0.162 & 0.104 & 0.132 & 0.103 & 0.238 & 0.473 \\
\hline & $(0.043)^{* * *}$ & $(0.151)$ & $(0.047)^{* * *}$ & $(0.154)$ & $(0.096)^{* *}$ & $(0.313)$ \\
\hline Controls & No & Yes & No & Yes & No & Yes \\
\hline$N$ & 148 & 148 & 106 & 106 & 42 & 42 \\
\hline$R^{2}$ & 0.047 & 0.174 & 0.027 & 0.145 & 0.115 & 0.445 \\
\hline \multicolumn{7}{|l|}{ Panel B } \\
\hline \multirow[t]{2}{*}{ Malaysia } & 0.124 & 0.123 & 0.099 & 0.109 & 0.206 & 0.036 \\
\hline & $(0.098)$ & $(0.111)$ & $(0.105)$ & $(0.121)$ & $(0.235)$ & $(0.326)$ \\
\hline \multirow[t]{2}{*}{ Singapore } & 0.248 & 0.255 & 0.164 & 0.145 & 0.429 & 0.392 \\
\hline & $(0.097)^{* *}$ & $(0.093)^{*}$ & $(0.106)$ & $(0.112)$ & $(0.204)^{*}$ & $(0.216)$ \\
\hline \multirow[t]{2}{*}{ Constant } & 0.162 & 0.143 & 0.132 & 0.114 & 0.238 & 0.399 \\
\hline & $(0.043)^{* * *}$ & $(0.151)$ & $(0.047)^{* * *}$ & $(0.153)$ & $(0.098)^{* *}$ & $(0.248)$ \\
\hline Controls & No & Yes & No & Yes & No & Yes \\
\hline$F($ Singapore $=$ Malaysia $)$ & 1.25 & 1.36 & 0.28 & 0.07 & 0.97 & 1.17 \\
\hline$N$ & 148 & 148 & 106 & 106 & 42 & 42 \\
\hline$R^{2}$ & 0.057 & 0.184 & 0.031 & 0.146 & 0.140 & 0.484 \\
\hline
\end{tabular}

Standard errors (clustered at the company level) are in parentheses. Controls include week fixed effects, resume template fixed effects, resume cover letter fixed effects, gender of an applicant, and a dummy indicating if a resume is associated with an address in a rich neighborhood. The F-statistics are $F$-tests for the Singapore and Malaysia effects being equal ${ }^{*} p<0.10$; ${ }^{* *} p<0.05$; ${ }^{* * *} p<0.01$. $p$ values are adjusted for multiple hypothesis tests using Holm's method (Holm 1979) 
find a much smaller and insignificant effect for local employers who are on average 13.2 percentage points more likely to first call back an applicant with foreign experience, or a $100 \%$ effect relative to the baseline estimate of 13.2 percentage points (column 3).

I next analyze if the effect of listing programming skills acquired in the Singapore software industry differs from that of the Malaysia software industry. With a population of approximately 5.5 million people ${ }^{10}$ and skilled migrants constituting over one third of its labor force, ${ }^{11}$ Singapore is more economically developed than Malaysia, and both countries are more developed than Myanmar in many aspects. Home to leading multinational IT corporations such as IBM, the Singapore software industry is considered the most developed among Southeast Asian nations and the skill level of its labor force is high compared with that of other Southeast Asian nations. The results listed in Table 4 panel B show that resumes listing work experience in the Singapore software industry are on average 24.8 percentage points more likely than local applicants to receive callbacks first from employers, and the difference is statistically significant at the $5 \%$ level (column 1); the point estimate is robust to the inclusion of controls in column 2 . When breaking down by employer type, I find that the coefficient of Singapore experience is (1) smaller and insignificant among local employers in column 3 (a $124 \%$ effect relative to the baseline estimate of 13.2 percentage points) and (2) larger and significant at the 10\% level among foreign employers in column 5 (a 183\% effect relative to the baseline estimate of 23.8 percentage points). This again suggests that the initial estimated effect of Singapore experience reported in column 1 is mainly due to foreign employers.

I next examine the return to listing accounting skills acquired in Singapore and Malaysia. Accounting jobs make up $46 \%$ of the sample job openings, with most accounting jobs requiring (1) at least a degree; (2) knowledge of accounting software; (3) local accounting experience and practices; (4) internationally recognized qualifications such as London Chamber of Commerce \& Industry (LCCI); or (5) a

Table 5 Dependent variable: if a resume is the first to receive a callback for an interview (accountant)

\begin{tabular}{|c|c|c|c|c|}
\hline & \multicolumn{2}{|l|}{ Local } & \multicolumn{2}{|l|}{ Foreign } \\
\hline & $\begin{array}{l}\text { Accountant } \\
\text { (1) }\end{array}$ & $\begin{array}{l}\text { Senior accountant } \\
\text { (2) }\end{array}$ & $\begin{array}{l}\text { Accountant } \\
\text { (3) }\end{array}$ & $\begin{array}{l}\text { Senior accountant } \\
\text { (4) }\end{array}$ \\
\hline \multirow[t]{2}{*}{ Malaysia } & -0.049 & -0.038 & -0.078 & -0.160 \\
\hline & $(0.043)$ & $(0.050)$ & $(0.087)$ & $(0.076)$ \\
\hline \multirow[t]{2}{*}{ Singapore } & -0.071 & 0.010 & 0.090 & -0.031 \\
\hline & $(0.042)$ & $(0.051)$ & $(0.155)$ & $(0.096)$ \\
\hline \multirow[t]{2}{*}{ Constant } & 0.181 & 0.223 & 0.298 & 0.160 \\
\hline & $(0.090)^{* *}$ & $(0.121)^{*}$ & $(0.268)$ & $(0.181)$ \\
\hline Controls & Yes & Yes & Yes & Yes \\
\hline F(Singapore = Malaysia) & 0.28 & 0.77 & 1.07 & 1.83 \\
\hline N & 396 & 324 & 88 & 80 \\
\hline$R^{2}$ & 0.087 & 0.054 & 0.233 & 0.300 \\
\hline
\end{tabular}

Standard errors (clustered at the company level) are in parentheses. Controls include week fixed effects, resume template fixed effects, resume cover letter fixed effects, gender of an applicant, and a dummy indicating if a resume is associated with an address in a rich neighborhood. The F-statistics are F-tests for the Singapore and Malaysia effects being equal ${ }^{*} p<0.10$; ${ }^{* *} p<0.05$; ${ }^{* * *} p<0.01 . p$ values are adjusted for multiple hypothesis tests using Holm's method (Holm 1979) 
professional license such as Certificate in Public Accounting (CPA). Table 5 lists the OLS results for the subsample of accounting jobs by employer type and by seniority (accountant/senior accountant). The coefficients for the Malaysia experience have negative signs across the four columns but fail to be significant. The coefficients for the Singapore experience have inconsistent signs and are not significant either. The possible explanation for the insignificant effects may be due to the fact that, in most countries, accounting practices tend to be country-specific. For instance, accounting practitioners are required to be certified by local professional and statutory boards, and company financial reports are also required to be prepared and approved by locally certified accountants. This suggests that accounting skills acquired in foreign labor markets are less transferrable to and do not always enhance productivity in home countries. In Myanmar, the Myanmar Accountancy Council (MAC) is the main body responsible for regulating accounting practices and issuing professional licenses, including the Certified Public Accountant (CPA) certificate that is subject to annual renewal.

Engineers are the second largest occupation group, making up 39\% of the sample job openings. Table 6 panel A presents the OLS estimates for the subsample of engineers, which show that the effects of engineering experience accumulated in

Table 6 Dependent variable: if a resume is the first to receive a callback for an interview (engineer)

\begin{tabular}{llll}
\hline & Local and foreign & Local & Foreign \\
& $(1)$ & $(2)$ & $(3)$ \\
\hline Panel A (engineer) & & & 0.036 \\
Malaysia & -0.001 & -0.006 & $(0.098)$ \\
& $(0.034)$ & $(0.037)$ & 0.037 \\
Singapore & -0.007 & -0.008 & $(0.078)$ \\
& $(0.032)$ & $(0.036)$ & 0.331 \\
Constant & 0.140 & 0.099 & $(0.143)^{* *}$ \\
& $(0.059)^{* *}$ & $(0.060)$ & Yes \\
Controls & Yes & Yes & 0.00 \\
$F($ Singapore $=$ Malaysia) & 0.03 & 0.00 & 158 \\
$N$ & 752 & 594 & 0.114 \\
$R^{2}$ & 0.032 & 0.055 & \\
Panel B (civil engineer) & & & 0.030 \\
Malaysia & -0.047 & -0.060 & $(0.155)$ \\
& $(0.053)$ & $(0.059)$ & -0.062 \\
Singapore & -0.024 & -0.012 & $(0.139)$ \\
F(Singapore $=$ Malaysia) & $(0.056)$ & $(0.067)$ & 0.032 \\
Constant & 0.118 & 0.120 & $(0.245)$ \\
$R^{2}$ & $(0.082)$ & $(0.090)$ & Yes \\
Yes & 0.14 & Yes & 0.156 \\
\hline
\end{tabular}

Standard errors (clustered at the company level) are in parentheses. Controls include week fixed effects, resume template fixed effects, resume cover letter fixed effects, gender of an applicant, and a dummy indicating if a resume is associated with an address in a rich neighborhood. The F-statistics are $F$-tests for the Singapore and Malaysia effects being equal ${ }^{*} p<0.10$; ${ }^{* *} p<0.05 ;{ }^{* * *} p<0.01 . p$ values are adjusted for multiple hypothesis tests using Holm's method (Holm 1979) 
Singapore and Malaysia are not statistically significant (column 1), and this is true for local employers (column 2), as well as for foreign employers (column 3). To assess if the effects differ by engineering discipline, I present separate results in Table 6 panel B paying attention to civil engineering jobs, which make up 40\% of all engineering jobs. The results are qualitatively similar to those presented in panel A, with no discernible effects of foreign experience found for civil engineers. The lack of significant effects found for engineers and civil engineering could be due to two primary reasons. First, given that the construction and housing industry in Myanmar is still in its developmental stage, it will take several years before more advanced construction technology and engineering practices are widely adopted by Myanmar companies. This suggests that engineering and construction skills acquired in more advanced countries could be less transferable to local context. Second, since the Myanmar construction industry is heavily regulated, employment in the industry requires extensive knowledge about local rules and regulations as well as the ability to navigate through complex bureaucracies efficiently, rendering overseas experience less valuable to local employers.

This study finds that $15 \%$ of employers call back both applicants, $13 \%$ call back only one applicant (out of two), and $72 \%$ do not call back any applicants (Table 2). As a robustness check, I also analyze callback patterns focusing on the $13 \%$ of employers that call back only one applicant. As this sample restriction results in a substantial decrease in the sample size, I group the Malaysia and Singapore experiences into one group to enhance statistical power. The OLS estimates presented in Table 7 are qualitatively similar to the previous results. The results indicate that when deciding to call back one applicant (out of two), employers hiring software developers and engineers are more likely to call back return migrants than nonmigrants for interviews.

\section{Conclusions}

As the Myanmar economy continues to grow and further undergoes transformation in the coming years, a chronic shortage of sufficiently skilled workers will continue to be a pressing issue for Myanmar employers. One promising solution would be to tap into the skills of return migrants who have been returning home to take

Table 7 Dependent variable: if a resume receives a callback conditional on employers that call back one applicant out of two

\begin{tabular}{|c|c|c|c|c|c|c|}
\hline \multirow[t]{2}{*}{ Occupation } & \multicolumn{2}{|c|}{ Software developer } & \multicolumn{2}{|c|}{ Accountant } & \multicolumn{2}{|l|}{ Engineer } \\
\hline & (1) & $(2)$ & (3) & (4) & (5) & (6) \\
\hline \multirow[t]{2}{*}{ Foreign experience } & 0.455 & 0.623 & -0.246 & -0.182 & 0.208 & 0.230 \\
\hline & $(0.289)$ & $(0.358)$ & $(0.126)^{*}$ & $(0.136)$ & $(0.136)$ & $(0.141)$ \\
\hline \multirow[t]{2}{*}{ Constant } & 0.273 & 0.678 & 0.623 & 0.480 & 0.396 & 0.266 \\
\hline & $(0.144)^{*}$ & $(0.329)^{*}$ & $(0.063)^{* * *}$ & $(0.156)^{* * *}$ & $(0.068)^{* * *}$ & $(0.139)^{*}$ \\
\hline Controls & No & Yes & No & Yes & No & Yes \\
\hline N & 22 & 22 & 122 & 122 & 106 & 106 \\
\hline$R^{2}$ & 0.207 & 0.855 & 0.060 & 0.197 & 0.043 & 0.234 \\
\hline
\end{tabular}

Standard errors (clustered at the company level) are in parentheses. Controls include week fixed effects, resume template fixed effects, resume cover letter fixed effects, gender of an applicant, and a dummy indicating if a resume is associated with an address in a rich neighborhood

${ }^{*} p<0.10$; ${ }^{* *} p<0.05 ;{ }^{* * *} p<0.01$. $p$ values are adjusted for multiple hypothesis tests using Holm's method (Holm 1979) 
advantage of increased economic opportunities since the country opened up in 2011. Yet little is known about how much demand exists for skills and experience that return migrants acquired in foreign labor markets. In this study, I analyze the employment outcomes of returnees, which has received little attention in the extant literature. Despite prior studies showing that returnees are more likely to earn higher wages than non-migrants (Wahba 2015; Reinhold and Thom 2013; Co et al. 2000; Barrett and Goggin 2010; Martin and Radu 2012), a host of factors including a lack of characteristics crucial for finding employment and performing well on a job in local context (e.g., social ties and connections) and a mismatch of skills could inhibit their full participation in local labor markets (Sun 2013; Martin and Radu 2012).

Overall, I find limited impact of foreign work experience on employment outcomes in the Myanmar labor market. This however masks a great deal of heterogeneity by occupation, employer type, and foreign country where such experience was accumulated. In particular, I find that programming skills acquired in the Singapore software industry are valued by employers in Myanmar, in particular foreign employers, while the same skills acquired in Malaysia have no discernible impact. These findings are consistent with (1) the industrial trend that the Myanmar software industry is still in its infancy as a result of years of isolation that restricted inflow of IT technologies, personnel, and tech firms from more developed foreign countries and (2) the fact that the Singapore software industry is more developed than Malaysia. In contrast, my results do not suggest that accounting and engineering skills acquired in Singapore and Malaysia are favored by employers in Myanmar, with the possible explanation being that accounting and engineering practices tend to be country- or local-specific. My findings seem to be in line with prior findings indicating that some skills acquired overseas are less transferrable to a local labor market and, thus, do not always translate into improved productivity (e.g., Sun 2013).

One caveat of this study is that since the sample only involves current job seekers, the results may not be generalizable to returnees who are currently employed, out of the labor force, or self-employed. That said, given anecdotal evidence that a large percentage of skilled Myanmar migrants are returning (coupled with the Myanmar government's efforts to reach out to the Myanmar diaspora population), a focus on job seekers will be of particular interest to policy makers, as well as to migrants planning on returning.

One direct policy implication arising from this research is that return migration policies targeting specific occupations and employers will be more effective than a single policy targeting all occupations and employers. Bilateral exchange programs enabling workers to spend a certain period in a foreign country to acquire and develop specific skills and policies incentivizing the inflow of foreign expertise and investment in lagging industries (e.g., software) will be helpful in strengthening job skills in Myanmar.

While findings from this research shed some light on the relationship between foreign experience and employment outcomes, more research is needed to uncover the possible underlying mechanisms that might explain systematic variation in employers' hiring decisions and the interactions between various mechanisms. One plausible mechanism may be that employers might worry that local applicants may 
lack language skills to effectively communicate with foreign clients. On the other hand, employers might worry that returnees may lack required social skills in the local context after years of absence and thus may not perform well on a job, thereby offsetting potential benefit to foreign experience. Another potential channel is verification of overseas skills. Bilateral programs between Myanmar and foreign countries that verify, register, and certify skills returnees accumulated abroad are lacking. This suggests that (1) difficulty in independently assessing the authenticity of foreign experience with foreign employers, (2) difficulty in assessing the quality of foreign skills, and (3) a mismatched belief between employers and returnees about the quality of foreign skills could negatively affect employment prospects for returnees. Another channel would be a wage level that is higher in Singapore and Malaysia than Myanmar across most occupations. Given this wage differential, employers might also be concerned that returnees might require a high level of compensation, thus making them less attractive to potential employers; in practice, the salary effect can be estimated by randomly varying the salary requirement. This study did randomly vary salary requirement; however, this was not designed to pick up the salary effect. Rather, it was mainly meant to comply with one of the application requirements that applicants listed salary requirements in the resumes; failure to do so would (1) either disqualify an applicant or (2) result in an employer repeatedly calling an applicant asking for a salary requirement, which would then undermine the validity of the experiment. Most importantly, my resume design did not generate meaningful variation in salary requirement as each resume pair was randomly assigned salary requirements that were almost identical to ensure uniformity.

By focusing on the Singapore and Malaysia labor markets whose characteristics are fundamentally similar to those of Myanmar in terms of political rights, we can rule out Myanmar employers' concern that returnees who have been exposed to the Singapore and Malaysia labor markets might demand excessive political rights and stage protests. To address the concern that potential employers might infer labor productivity from prior work experience, each resume was randomly assigned three companies where applicants previously worked from a list of companies carefully chosen from company registries based on two criteria: they (1) are of small size and (2) lack reputation and recognition at the national and international levels.

Given limited prior research on this topic, further research is needed before firm conclusions about the labor market outcomes of returning Myanmar migrants can be established. In particular, any future research conducting in-depth interviews with hiring personnel, exploring additional mechanisms, gauging the importance of each mechanism, disentangling the effects of each of the possible mechanisms, and illuminating how these mechanisms interact with each other are encouraged and can better inform policy decisions. The Myanmar financial and banking sector will see a substantial growth and may become an engine of economic growth in the coming years as a result of the recent liberalization of the financial industry. Thus, future studies analyzing employment outcomes of returnees focusing on occupations in the Myanmar banking and finance industry (e.g., financial, risk, and credit analyst) will be very helpful.

Despite the recent growth in the private sector's total employment share, the Myanmar government is still the largest single employer accounting for $10-20 \%$ of 
total employment. Since taking office in March 2016, the current government has been launching numerous outreach programs (via its foreign embassies) encouraging Myanmar citizens living abroad to return home. Yet, it remains unclear how returnees can be successfully integrated into the highly bureaucratic government sector. Thus, the same analysis should be extended to government employment in any future research.

\section{Endnotes}

${ }^{1}$ The only study I am aware of that examined the employment status of returnees is Saarela and Finnäs (2009), who found that the chance of employment for returning Finns is half that of non-migrants. This employment difference is stable over time after their return and is robust across different socioeconomic groups. However, this estimate is likely to suffer from selection bias, as the analysis simply regresses the employment status on migration status, controlling for observables. Martin and Radu (2012) is another study that analyzes employment patterns of return migrants in Eastern European countries and finds return migrants are more likely to become unemployed in the first year after their returns.

${ }^{2}$ For instance, Clemens (2013) exploits a US H-1B visa lottery program that exogenously determines whether an Indian software worker works in India or in the USA and finds that an average software developer earns US\$ 55,000, more than an equivalent worker in India. Likewise, McKenzie et al. (2010), exploiting outcomes from a lottery program used to admit migrants from Tonga to New Zealand, find that migrants on average see a $263 \%$ increase in income 1 year after arriving in New Zealand.

${ }^{3}$ In fact, some skilled migrants have already returned home to take advantage of new economic opportunities that have been created since the country opened up in 2011. See, for instance, http://www.straitstimes.com/asia/se-asia/the-return-of-the-burmese-diaspora.

${ }^{4}$ The two company registries: (1) the 2014 Edition of the Yangon Directory (http:// www.yangondirectory.com/en/) and (2) the Singapore Company Directory (http:// singapore-companies-directory.com/). Each registry lists over 50,000 company names sorted by industry.

${ }^{5}$ http://data.worldbank.org/indicator/BX.KLT.DINV.CD.WD

${ }^{6}$ Most Myanmar-based foreign companies are from other Asian countries-in particular from Singapore, Thailand, China, India, Korea, and Japan.

${ }^{7}$ http://www.irrawaddy.com/business/world-bank-forecasts-7-8-growth-burmayear.html

${ }^{8}$ Regression results using standard outcomes are provided in the Appendix 2 for comparison with other studies. Appendix 3 provides Probit regressions results as robustness checks using if a resume is the first to receive a callback for an interview as outcome variable.

${ }^{9}$ For instance, the Yangon Institute of Technology, the premier engineering university in Myanmar, was established as the Department of Engineering under Rangoon University in 1924.

${ }^{10} \mathrm{http}$ ///www.singstat.gov.sg/statistics/browse-by-theme/population-and-populationstructure

${ }^{11}$ http://stats.mom.gov.sg/Pages/Labour-Force-Summary-Table.aspx 


\section{Appendix 1}

Table 8 Distribution of sample job openings

\begin{tabular}{lll}
\hline & Frequency & Percent \\
\hline Accountant & 242 & 24.97 \\
Senior accountant & 202 & 20.85 \\
Architect & 13 & 1.34 \\
Draftsmen & 22 & 2.27 \\
Software developer and programmer & 74 & 7.64 \\
IT technician & 62 & 6.40 \\
Civil engineer & 150 & 15.48 \\
Mechanical, electrical, and electronic engineer & 87 & 8.98 \\
General engineer & 7 & 0.72 \\
Junior civil engineer & 9 & 0.93 \\
Project engineer or project manager & 52 & 5.37 \\
Assistant chief engineer & 3 & 0.31 \\
Assistant engineer & 3 & 0.31 \\
Senior civil engineer & 8 & 0.83 \\
Sales engineer & 4 & 0.41 \\
Service engineer & 18 & 1.86 \\
Nurse or pharmacist & 11 & 1.14 \\
Other & 2 & 0.21 \\
Total & 969 & 100 \\
\hline
\end{tabular}

Appendix 2

Table 9 Dependent variable: if a resume receives a callback for an interview (all occupations)

\begin{tabular}{|c|c|c|c|c|c|c|}
\hline & \multicolumn{2}{|c|}{ Local and foreign } & \multicolumn{2}{|l|}{ Local } & \multicolumn{2}{|l|}{ Foreign } \\
\hline & (1) & (2) & (3) & (4) & (5) & (6) \\
\hline \multicolumn{7}{|l|}{ Panel A } \\
\hline \multirow[t]{2}{*}{ Foreign experience } & -0.001 & -0.002 & -0.004 & -0.005 & 0.010 & 0.006 \\
\hline & $(0.012)$ & $(0.012)$ & $(0.013)$ & $(0.013)$ & $(0.027)$ & $(0.029)$ \\
\hline \multirow[t]{2}{*}{ Constant } & 0.218 & 0.310 & 0.207 & 0.256 & 0.260 & 0.584 \\
\hline & $(0.013)^{* * *}$ & $(0.063)^{* * *}$ & $(0.015)^{* * *}$ & $(0.065)^{* * *}$ & $(0.031)^{* * *}$ & $(0.172)^{* * *}$ \\
\hline Controls & No & Yes & No & Yes & No & Yes \\
\hline$N$ & 1938 & 1938 & 1538 & 1538 & 400 & 400 \\
\hline$R^{2}$ & 0.000 & 0.029 & 0.000 & 0.034 & 0.000 & 0.083 \\
\hline \multicolumn{7}{|l|}{ Panel B } \\
\hline \multirow[t]{2}{*}{ Malaysia } & 0.004 & -0.000 & 0.004 & -0.001 & 0.009 & 0.000 \\
\hline & $(0.018)$ & $(0.018)$ & $(0.020)$ & $(0.020)$ & $(0.042)$ & $(0.042)$ \\
\hline \multirow[t]{2}{*}{ Singapore } & -0.006 & -0.003 & -0.012 & -0.010 & 0.011 & 0.012 \\
\hline & $(0.018)$ & $(0.018)$ & $(0.019)$ & $(0.019)$ & $(0.042)$ & $(0.043)$ \\
\hline \multirow[t]{2}{*}{ Constant } & 0.218 & 0.310 & 0.207 & 0.256 & 0.260 & 0.584 \\
\hline & $(0.013)^{* * *}$ & $(0.063)^{* * *}$ & $(0.015)^{* * *}$ & $(0.065)^{* * *}$ & $(0.031)^{* * *}$ & $(0.173)^{* * *}$ \\
\hline Controls & No & Yes & No & Yes & No & Yes \\
\hline$N$ & 1938 & 1938 & 1538 & 1538 & 400 & 400 \\
\hline$R^{2}$ & 0.000 & 0.029 & 0.000 & 0.034 & 0.000 & 0.083 \\
\hline
\end{tabular}

Standard errors (clustered at the company level) are in parentheses. Controls include week fixed effects, resume template fixed effects, resume cover letter fixed effects, gender of an applicant, and a dummy indicating if a resume is associated with an address in a rich neighborhood ${ }^{*} p<0.10 ;{ }^{* *} p<0.05 ;{ }^{* * *} p<0.01$ 
Table 10 Dependent variable: if a resume receives a callback for an interview (software developer/ programmer)

\begin{tabular}{|c|c|c|c|c|c|c|}
\hline & \multicolumn{6}{|c|}{ Software developer/programmer } \\
\hline & \multicolumn{2}{|c|}{ Local and foreign } & \multicolumn{2}{|l|}{ Local } & \multicolumn{2}{|l|}{ Foreign } \\
\hline & (1) & (2) & (3) & (4) & (5) & (6) \\
\hline \multicolumn{7}{|l|}{ Panel A } \\
\hline \multirow[t]{2}{*}{ Foreign experience } & 0.068 & 0.076 & 0.057 & 0.086 & 0.095 & 0.051 \\
\hline & $(0.045)$ & $(0.045)^{*}$ & $(0.050)$ & $(0.055)$ & $(0.096)$ & $(0.112)$ \\
\hline \multirow[t]{2}{*}{ Constant } & 0.405 & 0.458 & 0.302 & 0.478 & 0.667 & 0.891 \\
\hline & $(0.058)^{* * *}$ & $(0.279)$ & $(0.064)^{* * *}$ & $(0.287)$ & $(0.107)^{* * *}$ & $(0.119)^{* * *}$ \\
\hline Controls & No & Yes & No & Yes & No & Yes \\
\hline N & 148 & 148 & 106 & 106 & 42 & 42 \\
\hline$R^{2}$ & 0.005 & 0.121 & 0.004 & 0.122 & 0.011 & 0.384 \\
\hline \multicolumn{7}{|l|}{ Panel B } \\
\hline \multirow[t]{2}{*}{ Malaysia } & 0.080 & 0.110 & 0.083 & 0.117 & 0.111 & 0.258 \\
\hline & $(0.076)$ & $(0.079)$ & $(0.082)$ & $(0.090)$ & $(0.141)$ & $(0.160)$ \\
\hline \multirow[t]{2}{*}{ Singapore } & 0.056 & 0.044 & 0.031 & 0.054 & 0.083 & -0.117 \\
\hline & $(0.072)$ & $(0.071)$ & $(0.086)$ & $(0.095)$ & $(0.134)$ & $(0.154)$ \\
\hline \multirow[t]{2}{*}{ Constant } & 0.405 & 0.438 & 0.302 & 0.459 & 0.667 & 0.969 \\
\hline & $(0.058)^{* * *}$ & $(0.283)$ & $(0.064)^{* * *}$ & $(0.291)$ & $(0.108)^{* * *}$ & $(0.128)^{* * *}$ \\
\hline Controls & No & Yes & No & Yes & No & Yes \\
\hline$N$ & 148 & 148 & 106 & 106 & 42 & 42 \\
\hline$R^{2}$ & 0.005 & 0.123 & 0.005 & 0.124 & 0.012 & 0.435 \\
\hline
\end{tabular}

Standard errors (clustered at the company level) are in parentheses. Controls include week fixed effects, resume template fixed effects, resume cover letter fixed effects, gender of an applicant, and a dummy indicating if a resume is associated with an address in a rich neighborhood

${ }^{*} p<0.10$; ${ }^{* *} p<0.05 ;{ }^{* * *} p<0.01$

Table 11 Dependent variable: if a resume receives a callback for an interview (accountant)

\begin{tabular}{|c|c|c|c|c|}
\hline & \multicolumn{2}{|l|}{ Local } & \multicolumn{2}{|l|}{ Foreign } \\
\hline & Accountant & Senior accountant & Accountant & Senior accountant \\
\hline & (1) & (2) & (3) & (4) \\
\hline \multirow[t]{2}{*}{ Malaysia } & -0.017 & -0.048 & 0.081 & -0.124 \\
\hline & $(0.038)$ & $(0.040)$ & $(0.100)$ & $(0.064)^{*}$ \\
\hline \multirow[t]{2}{*}{ Singapore } & -0.068 & -0.015 & 0.048 & -0.033 \\
\hline & $(0.036)^{*}$ & $(0.047)$ & $(0.143)$ & $(0.097)$ \\
\hline \multirow[t]{2}{*}{ Constant } & 0.207 & 0.342 & 0.580 & 0.163 \\
\hline & $(0.118)^{*}$ & $(0.193)^{*}$ & $(0.425)$ & $(0.187)$ \\
\hline Controls & Yes & Yes & Yes & Yes \\
\hline N & 396 & 324 & 88 & 80 \\
\hline$R^{2}$ & 0.102 & 0.078 & 0.239 & 0.268 \\
\hline
\end{tabular}

Standard errors (clustered at the company level) are in parentheses. Controls include week fixed effects, resume template fixed effects, resume cover letter fixed effects, gender of an applicant, and a dummy indicating if a resume is associated with an address in a rich neighborhood

${ }^{*} p<0.10 ;{ }^{* *} p<0.05 ;{ }^{* * *} p<0.01$ 
Table 12 Dependent variable: if a resume receives a callback for an interview (engineer)

\begin{tabular}{llll}
\hline & Local and foreign & Local & Foreign \\
& $(1)$ & $(2)$ & $(3)$ \\
\hline Panel A (engineer) & & & 0.030 \\
Malaysia & 0.032 & 0.032 & $(0.078)$ \\
& $(0.031)$ & $(0.034)$ & 0.069 \\
Singapore & 0.020 & 0.018 & $(0.059)$ \\
& $(0.028)$ & $(0.031)$ & 0.699 \\
Constant & 0.202 & 0.104 & $(0.252)^{* * *}$ \\
& $(0.093)^{* *}$ & $(0.085)$ & Yes \\
Controls & Yes & Yes & 158 \\
$N$ & 752 & 594 & 0.230 \\
$R^{2}$ & 0.051 & 0.082 & \\
Panel B (civil engineer) & & & 0.132 \\
Malaysia & -0.044 & -0.072 & $(0.108)$ \\
& $(0.051)$ & $(0.058)$ & 0.053 \\
Singapore & 0.071 & 0.075 & $(0.130)$ \\
& $(0.050)$ & $(0.060)$ & 0.013 \\
Constant & 0.158 & 0.149 & $(0.354)$ \\
& $(0.117)$ & $(0.127)$ & Yes \\
Controls & Yes & Yes & 70 \\
$N$ & 300 & 230 & 0.224 \\
\hline$R^{2}$ & 0.069 & 0.122 & \\
\hline
\end{tabular}

Standard errors (clustered at the company level) are in parentheses. Controls include week fixed effects, resume template fixed effects, resume cover letter fixed effects, gender of an applicant, and a dummy indicating if a resume is associated with an address in a rich neighborhood ${ }^{*} p<0.10 ;{ }^{* *} p<0.05 ;{ }^{* * *} p<0.01$

\section{Appendix 3}

Probit regressions

Table 13 Dependent variable: if a resume is the first to receive a callback for an interview (all occupations)

\begin{tabular}{|c|c|c|c|c|c|c|}
\hline & \multicolumn{2}{|c|}{ Local and foreign } & \multicolumn{2}{|l|}{ Local } & \multicolumn{2}{|l|}{ Foreign } \\
\hline & (1) & (2) & (3) & (4) & (5) & (6) \\
\hline \multicolumn{7}{|l|}{ Panel A } \\
\hline \multirow[t]{2}{*}{ Foreign experience } & -0.032 & -0.030 & -0.060 & -0.061 & 0.059 & 0.037 \\
\hline & $(0.076)$ & $(0.076)$ & $(0.087)$ & $(0.087)$ & $(0.161)$ & $(0.165)$ \\
\hline \multirow[t]{2}{*}{ Constant } & -1.056 & -0.927 & -1.078 & -1.026 & -0.974 & -0.462 \\
\hline & $(0.050)^{* * *}$ & $(0.158)^{* * *}$ & $(0.056)^{* * *}$ & $(0.181)^{* * *}$ & $(0.106)^{* * *}$ & $(0.320)$ \\
\hline Controls & No & Yes & No & Yes & No & Yes \\
\hline$N$ & 1938 & 1938 & 1538 & 1538 & 400 & 400 \\
\hline Pseudo $R^{2}$ & 0.000 & 0.021 & 0.000 & 0.028 & 0.000 & 0.041 \\
\hline \multicolumn{7}{|l|}{ Panel B } \\
\hline \multirow[t]{2}{*}{ Malaysia } & -0.067 & -0.079 & -0.055 & -0.073 & -0.107 & -0.178 \\
\hline & $(0.092)$ & $(0.093)$ & $(0.104)$ & $(0.105)$ & $(0.201)$ & $(0.204)$ \\
\hline \multirow[t]{2}{*}{ Singapore } & 0.001 & 0.017 & -0.066 & -0.048 & 0.185 & 0.194 \\
\hline & $(0.090)$ & $(0.090)$ & $(0.104)$ & $(0.104)$ & $(0.184)$ & $(0.188)$ \\
\hline \multirow[t]{2}{*}{ Constant } & -1.056 & -0.922 & -1.078 & -1.025 & -0.974 & -0.444 \\
\hline & $(0.050)^{* * *}$ & $(0.158)^{* * *}$ & $(0.056)^{* * *}$ & $(0.181)^{* * *}$ & $(0.106)^{* * *}$ & $(0.328)$ \\
\hline Controls & No & Yes & No & Yes & No & Yes \\
\hline$N$ & 1938 & 1938 & 1538 & 1538 & 400 & 400 \\
\hline Pseudo $R^{2}$ & 0.000 & 0.022 & 0.000 & 0.028 & 0.006 & 0.049 \\
\hline
\end{tabular}

Standard errors (clustered at the company level) are in parentheses. Controls include week fixed effects, resume template fixed effects, resume cover letter fixed effects, gender of an applicant, and a dummy indicating if a resume is associated with an address in a rich neighborhood ${ }^{*} p<0.10$; ${ }^{* *} p<0.05 ;{ }^{* * *} p<0.01$ 
Table 14 Dependent variable: if a resume is the first to receive a callback for an interview (software developer/programmer)

\begin{tabular}{|c|c|c|c|c|c|c|}
\hline & \multicolumn{6}{|c|}{ Software developer/programmer } \\
\hline & \multicolumn{2}{|c|}{ Local and foreign } & \multicolumn{2}{|l|}{ Local } & \multicolumn{2}{|l|}{ Foreign } \\
\hline & $(1)$ & (2) & (3) & (4) & (5) & (6) \\
\hline \multicolumn{7}{|l|}{ Panel A } \\
\hline \multirow[t]{2}{*}{ Foreign experience } & 0.604 & 0.663 & 0.486 & 0.487 & 0.892 & 1.441 \\
\hline & $(0.266)^{* *}$ & $(0.290)^{* *}$ & $(0.320)$ & $(0.367)$ & $(0.535)^{*}$ & $(0.808)^{*}$ \\
\hline \multirow[t]{2}{*}{ Constant } & -0.986 & -1.419 & -1.117 & -1.614 & -0.712 & 0.676 \\
\hline & $(0.176)^{* * *}$ & $(0.566)^{* *}$ & $(0.220)^{* * *}$ & $(0.607)^{* * *}$ & $(0.308)^{* *}$ & $(0.867)$ \\
\hline Controls & No & Yes & No & Yes & No & Yes \\
\hline$N$ & 148 & 144 & 106 & 94 & 42 & 40 \\
\hline Pseudo $R^{2}$ & 0.042 & 0.154 & 0.028 & 0.138 & 0.087 & 0.431 \\
\hline \multicolumn{7}{|l|}{ Panel B } \\
\hline \multirow[t]{2}{*}{ Malaysia } & 0.420 & 0.460 & 0.380 & 0.439 & 0.573 & 0.355 \\
\hline & $(0.322)$ & $(0.370)$ & $(0.387)$ & $(0.446)$ & $(0.633)$ & $(0.810)$ \\
\hline \multirow[t]{2}{*}{ Singapore } & 0.759 & 0.869 & 0.582 & 0.537 & 1.143 & 2.570 \\
\hline & $(0.291)^{* * *}$ & $(0.300)^{* * *}$ & $(0.354)$ & $(0.404)$ & $(0.584)^{*}$ & $(1.280)^{* *}$ \\
\hline \multirow[t]{2}{*}{ Constant } & -0.986 & -1.269 & -1.117 & -1.576 & -0.712 & -0.156 \\
\hline & $(0.176)^{* * *}$ & $(0.567)^{* *}$ & $(0.220)^{* * *}$ & $(0.601)^{* * *}$ & $(0.308)^{* *}$ & (0.878) \\
\hline Controls & No & Yes & No & Yes & No & Yes \\
\hline$N$ & 148 & 144 & 106 & 94 & 42 & 40 \\
\hline Pseudo $R^{2}$ & 0.049 & 0.161 & 0.031 & 0.139 & 0.106 & 0.499 \\
\hline
\end{tabular}

Standard errors (clustered at the company level) are in parentheses. Controls include week fixed effects, resume template fixed effects, resume cover letter fixed effects, gender of an applicant, and a dummy indicating if a resume is associated with an address in a rich neighborhood

${ }^{*} p<0.10$; ${ }^{* *} p<0.05 ;{ }^{* * *} p<0.01$

Table 15 Dependent variable: if a resume is the first to receive a callback for an interview (accountant)

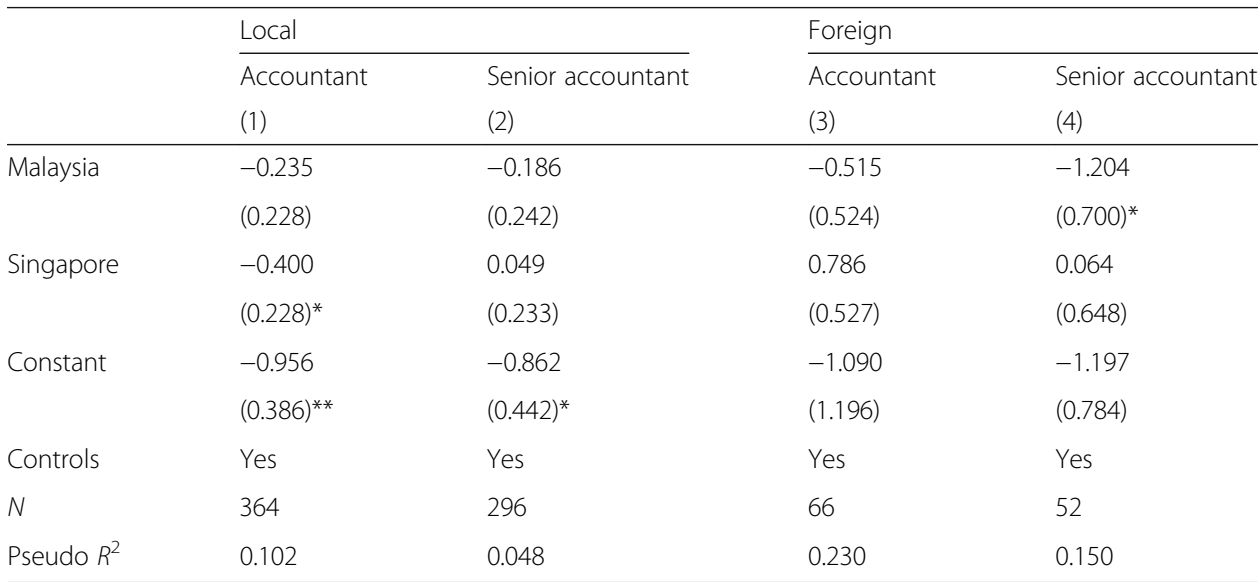

Standard errors (clustered at the company level) are in parentheses. Controls include week fixed effects, resume template fixed effects, resume cover letter fixed effects, gender of an applicant, and a dummy indicating if a resume is associated with an address in a rich neighborhood

${ }^{*} p<0.10 ;{ }^{* *} p<0.05 ;{ }^{* * *} p<0.01$ 
Table 16 Dependent variable: if a resume is the first to receive a callback for an interview (engineer)

\begin{tabular}{|c|c|c|c|}
\hline & $\begin{array}{l}\text { Local and foreign } \\
\text { (1) }\end{array}$ & $\begin{array}{l}\text { Local } \\
(2)\end{array}$ & $\begin{array}{l}\text { Foreign } \\
\text { (3) }\end{array}$ \\
\hline Panel A (engineer) & 0.002 & -0.035 & 0.151 \\
\hline \multirow[t]{2}{*}{ Malaysia } & $(0.150)$ & $(0.171)$ & $(0.372)$ \\
\hline & -0.035 & -0.027 & 0.194 \\
\hline \multirow[t]{2}{*}{ Singapore } & $(0.148)$ & $(0.175)$ & $(0.336)$ \\
\hline & -1.120 & -1.360 & -0.372 \\
\hline \multirow[t]{2}{*}{ Constant } & $(0.284)^{* * *}$ & $(0.344)^{* * *}$ & $(0.463)$ \\
\hline & 0.002 & -0.035 & 0.151 \\
\hline Controls & Yes & Yes & Yes \\
\hline$N$ & 752 & 586 & 146 \\
\hline Pseudo $R^{2}$ & 0.037 & 0.060 & 0.115 \\
\hline \multicolumn{4}{|c|}{ Panel B (civil engineer) } \\
\hline \multirow[t]{2}{*}{ Malaysia } & -0.215 & -0.305 & 0.115 \\
\hline & $(0.240)$ & $(0.283)$ & $(0.573)$ \\
\hline \multirow[t]{2}{*}{ Singapore } & -0.109 & -0.024 & -0.101 \\
\hline & $(0.252)$ & $(0.300)$ & $(0.769)$ \\
\hline \multirow[t]{2}{*}{ Constant } & -1.246 & -1.299 & -1.706 \\
\hline & $(0.432)^{* * *}$ & $(0.481)^{* * *}$ & $(0.812)^{* *}$ \\
\hline Controls & Yes & Yes & Yes \\
\hline$N$ & 286 & 212 & 56 \\
\hline Pseudo $R^{2}$ & 0.055 & 0.086 & 0.145 \\
\hline
\end{tabular}

Standard errors (clustered at the company level) are in parentheses. Controls include week fixed effects, resume template fixed effects, resume cover letter fixed effects, gender of an applicant, and a dummy indicating if a resume is associated with an address in a rich neighborhood

${ }^{*} p<0.10 ;{ }^{* *} p<0.05 ;{ }^{* * *} p<0.01$

Table 17 Dependent variable: If a resume receives a callback conditional on employers that call back one applicant out of two (Probit regression)

\begin{tabular}{|c|c|c|c|c|c|c|}
\hline \multirow[t]{2}{*}{ Occupation } & \multicolumn{2}{|c|}{ Software developer } & \multicolumn{2}{|c|}{ Accountant } & \multicolumn{2}{|c|}{ Engineer } \\
\hline & (1) & (2) & (3) & (4) & (5) & (6) \\
\hline \multirow[t]{2}{*}{ Foreign experience } & 1.209 & 5.318 & -0.626 & -0.539 & 0.526 & 0.689 \\
\hline & $(0.848)$ & $(1.059)^{* * *}$ & $(0.329)^{*}$ & $(0.349)$ & $(0.352)$ & $(0.384)^{*}$ \\
\hline \multirow[t]{2}{*}{ Constant } & -0.605 & -0.708 & 0.313 & -0.095 & -0.263 & -0.700 \\
\hline & $(0.424)$ & $(0.707)$ & $(0.165)^{*}$ & $(0.413)$ & $(0.176)$ & $(0.383)^{*}$ \\
\hline Controls & No & Yes & No & Yes & No & Yes \\
\hline N & 22 & 22 & 122 & 122 & 106 & 106 \\
\hline Pseudo $R^{2}$ & 0.155 & 0.523 & 0.044 & 0.158 & 0.031 & 0.184 \\
\hline
\end{tabular}

Standard errors (clustered at the company level) are in parentheses. Controls include week fixed effects, resume template fixed effects, resume cover letter fixed effects, gender of an applicant, and a dummy indicating if a resume is associated with an address in a rich neighborhood

${ }^{*} p<0.10 ;{ }^{* *} p<0.05 ;{ }^{* * *} p<0.01$ 


\section{Additional file}

Additional file 1: Sample resumes. (DOC $26 \mathrm{~kb}$ )

\section{Acknowledgements}

I thank John Gibson, David Powell, Arie Kapteyn, Silvia Helena Barcellos, and Erik Meijer for valuable feedback on a previous version this paper. Funding for this research was provided by Open Society Foundation through Civil Society Scholar Award (CSSA) and the Pardee RAND dissertation grant. I would also like to thank the anonymous referee and the editor for the useful remarks.

Responsible editor: David Lam

\section{Funding}

Funding for this research was provided by Open Society Foundation through Civil Society Scholar Award (CSSA) and the Pardee RAND dissertation grant.

\section{Competing interests}

The IZA Journal of Development and Migration is committed to the IZA Guiding Principles of Research Integrity. The author declares that he has observed these principles.

\section{Ethics approval and consent to participate}

Protocols, which form the basis for executing this research, were reviewed and approved by the Human Subjects Protection Committee at the RAND Corporation (Assurance number is FWA00003425; IRB number is IRB0000005).

\section{Publisher's Note}

Springer Nature remains neutral with regard to jurisdictional claims in published maps and institutional affiliations.

\section{Received: 25 October 2016 Accepted: 23 May 2017}

Published online: 11 January 2018

\section{References}

Ambrosini, J William, Karin Mayr, Giovanni Peri, and Dragos Radu. 2011. The selection of migrants and returnees: evidence from Romania and implications. National Bureau of Economic Research

Banerjee A, Bertrand M, Datta S, Mullainathan S. Labor market discrimination in Delhi: evidence from a field experiment. J Comp Econ. 2009;37(1):14-27.

Barrett A, Goggin J. Returning to the question of a wage premium for returning migrants. Natl Inst Econ Rev. 2010; 213(1):R43-51.

Barrett A, O Connell PJ. Is there a wage premium for returning Irish migrants? Econ Soc Rev. 2001:32(1):1-22.

Bertrand M, Mullainathan S. Are Emily and Greg more employable than Lakisha and Jamal: a field experiment on labor market discrimination. Am Econ Rev. 2004;94(991):1013.

Bóo FL, Rossi MA, Urzúa SS. The labor market return to an attractive face: evidence from a field experiment. Econ Lett. 2013;118(1):170-2

Carletto C, Kilic T. Moving up the ladder? The impact of migration experience on occupational mobility in Albania. J Dev Stud. 2011;47(6):846-69.

Clemens MA. Why do programmers earn more in Houston than Hyderabad? Evidence from randomized processing of US visas. Am Econ Rev. 2013;103(3):198-202

Co CY, Ira NG, Yun M-S. Returns to returning. J Popul Econ. 2000;13(1):57-79.

De Coulon A, Piracha M. Self-selection and the performance of return migrants: the source country perspective. J Popul Econ. 2005:18(4):779-807.

Dustmann C. Return migration, wage differentials, and the optimal migration duration. Eur Econ Rev. 2003;47(2):353-69.

Dustmann C, Kirchkamp O. The optimal migration duration and activity choice after re-migration. J Dev Econ. 2002; 67(2):351-72

Dustmann C, Weiss Y. Return migration: theory and empirical evidence from the UK. Br J Ind Relat. 2007;45(2):236-56

Dustmann C, Fadlon I, Weiss Y. Return migration, human capital accumulation and the brain drain. J Dev Econ. 2011; 95(1):58-67.

Galarza FB, Yamada G. Labor market discrimination in Lima, Peru: evidence from a field experiment. World Dev. 2014; 58:83-94.

Gibson J, McKenzie D. The microeconomic determinants of emigration and return migration of the best and brightest: evidence from the Pacific. J Dev Econ. 2011;95(1):18-29.

Holm S. 1979. "A simple sequentially rejective multiple test procedure." Scandinavian journal of statistics

Kroft K, Lange F, and Notowidigdo MJ. 2013. "Duration dependence and labor market conditions: evidence from a field experiment*." The Quarterly Journal of Economics. https://doi.org/10.1093/qje/qjt015

Lahey JN. Age, women, and hiring: an experimental study. J Human Res. 2008;43(1):30-56.

McCormick B, Wahba J. Overseas work experience, savings and entrepreneurship amongst return migrants to LDCs. Scot J Polit Econ. 2001:48(2):164-78.

McKenzie D. 2012. Learning about migration through experiments. Centre for Research and Analysis of Migration (CReAM), Department of Economics, University College London

McKenzie D, Stillman S, Gibson J. How important is selection? Experimental vs. non-experimental measures of the income gains from migration. J Eur Econ Assoc. 2010;8(4):913-45.

Mesnard A. Temporary migration and capital market imperfections. Oxf Econ Pap. 2004;56(2):242-62. 
Neumark D, Burn I, and Button P. 2015. Is it harder for older workers to find jobs? New and improved evidence from a field experiment. National Bureau of Economic Research

Oreopoulos P. Why do skilled immigrants struggle in the labor market? A field experiment with thirteen thousand resumes. Am Econ J: Econ Pol. 2011;3(4):148-71. https://doi.org/10.2307/41330445.

Reiner M, Radu D. Return migration: the experience of Eastern Europe. Int Migr. 2012;50(6):109-28.

Reinhold S, Thom K. Migration experience and earnings in the Mexican labor market. J Hum Res. 2013:48(3):768-820.

Saarela J, Finnäs F. Return migrant status and employment in Finland. Int J Manpow. 2009;30(5):489-506. https://doi.org/10.1108/01437720910977670

Sun W. The productivity of return migrants: the case of China's "Sea Turtles". IZA J Migr. 2013;2(1):1-19.

Wahba J. Selection, selection, selection: the impact of return migration. J Popul Econ. 2015;28(3):535-63.

Submit your manuscript to a SpringerOpen ${ }^{\circ}$ journal and benefit from:

- Convenient online submission

- Rigorous peer review

- Open access: articles freely available online

High visibility within the field

Retaining the copyright to your article

Submit your next manuscript at $\gg$ springeropen.com 